J Ga Public Health Assoc. 2016 ; 5(4): 304-313. doi:10.21663/jgpha.5.404.

\title{
A systematic review of lifestyle interventions for chronic diseases in rural communities
}

\author{
Selina A. Smith, PhD, MDiv ${ }^{1,2}$ and Benjamin Ansa, MD, MSCR ${ }^{1}$ \\ ${ }^{1}$ Institute of Public and Preventive Health, Augusta University, Augusta, GA \\ ${ }^{2}$ Department of Family Medicine, Medical College of Georgia, Augusta University, Augusta, GA
}

\begin{abstract}
Background-Rural Americans suffer disproportionately from lifestyle-related chronic diseases (e.g., obesity, diabetes, hypertension, cardiovascular disease, and breast cancer). Interventions that consider the distinctive characteristics of rural communities (e.g., access to healthcare, income, and education) are needed. As an initial step in planning future research, we completed a systematic review of dietary intake and physical activity interventions targeting rural populations.
\end{abstract}

Methods-Manuscripts focused on dietary intake and physical activity and published through March 15, 2016, were identified by use of PubMed and CINAHL databases and MeSH terms and keyword searches.

Results-A total of 18 studies met the inclusion criteria. Six involved randomized controlled trials; 7 used quasi-experimental designs; 4 had a pre-/post-design; and 1 was an observational study. Eight studies were multi-site (or multi-county), and 3 focused on churches. Primary emphasis by racial/ethnic group included: African Americans (6); Whites (2); Hispanics (3); and two or more groups (7). Most studies (17) sampled adults; one included children. Two studies targeted families.

Conclusions-Additional lifestyle intervention research is needed to identify effective approaches promoting healthy diet and exercise and chronic disease prevention in rural communities. Studies that include rigorous designs, adequate sample sizes, and generalizable results are needed to overcome the limitations of published studies.

\section{Keywords}

lifestyle intervention; dietary intake; physical activity; chronic disease; rural population

\footnotetext{
Originally published in jGPHA (http://www.gapha.org/jgpha/) June 15, 2016. This is an open-access article distributed under the terms of the Creative Commons Attribution Non-Commercial No-Derivatives License (http://creativecommons.org/licenses/by/4.0/), which permits unrestricted use, distribution, and reproduction in any medium, provided the original work ("first published in the Journal of the Georgia Public Health Association...") is properly cited with original URL and bibliographic citation information. The complete bibliographic information, a link to the original publication on http://www.gapha.jgpha.org/, as well as this copyright and license information must be included.

Corresponding Author: Dr. Benjamin Ansa, CJ2300, $112015^{\text {th }}$ Street, Augusta, GA 30912, 706-721-6141, bansa@ augusta.edu.
} 


\section{INTRODUCTION}

According to the United States Department of Agriculture (USDA, 2016), 17.5\% of people in Georgia live in rural areas. Rural communities have various poverty-related challenges that affect health and health outcomes (e.g., inadequate housing and transportation, communication issues, and limited education) (Drozek et al., 2014). Relative to the general population, rural Georgians experience higher incidences of disease and morbidity, increased mortality rates, and lower life expectancies. Financial burdens, labor-intensive work, social isolation, stress, and low accessibility to health care are determinants of health faced by rural residents (Bennett et al., 2013). Common among rural dwellers are limited access to health care, lack of health insurance, long distances traveled for routine checkups and screenings, fewer doctors and healthcare providers, and late stages of disease presentation.

Chronic diseases such as obesity, hypertension, cardiovascular disease, type 2 diabetes, and cancers are prevalent, costly, and preventable health problems. In 2012, almost half of all US adults (117 million people) had one or more chronic health condition, and one of four had two or more such conditions (Ward et al., 2014). Currently, the estimated prevalence of obesity for adults aged 18 years and older is $28.9 \%$ nationwide and $30.5 \%$ for the state of Georgia. Also, 9.3\% (29.1 million) of Americans and 9.9\% (734,800) of Georgians are diagnosed with diabetes; $29 \%$ (70 million) of Americans and 35\% of Georgians have hypertension; and $4.2 \%$ of American adults and $4.1 \%$ of Georgians have coronary heart disease (Levi et al., 2015; Blackwell et al., 2014). The 2016 estimates for new cases of invasive breast cancer are 246,660 for the US and 6,260 for Georgia (American Cancer Society [ACS], 2016; McNamara et al., 2015).

Many chronic diseases have associated lifestyle risk factors and are responsive to lifestyle modifications (Cecchini et al., 2010) (Figure 1). Lifestyle factors (e.g., excessive calories, refined carbohydrates, sodium, and fat; inadequate fiber; and lack of physical activity) as evidenced by risk indicators (e.g., elevated $\mathrm{HgA}_{1 \mathrm{c}}$ and blood pressure; unfavorable adipocytokines and serum lipids; and excessive body fat) are linked to chronic diseases (e.g., obesity, diabetes mellitus, hypertension, cardiovascular disease, and breast cancer).

Engaging in the recommended levels of physical activity and consuming a healthy diet can prevent several chronic diseases and reduce morbidity and mortality from these conditions (Willet et al., 2006). Adults with common chronic conditions who participate in comprehensive lifestyle modification programs experience rapid, significant, clinically meaningful, and sustainable improvements in biometric, laboratory, and psychosocial outcomes (Ricanati et al., 2011). Nearly $40 \%$ of all cancer deaths and $82 \%$ of cardiac deaths could be prevented and $91 \%$ of the cases of diabetes could be avoided through appropriate lifestyle changes, including adopting a simpler, healthier diet, and by following a consistent physical activity program (Aldana, 2005).

Although rural counties in the US have, relative to non-rural areas, higher rates of obesity, sedentary lifestyles, and associated chronic diseases, obesity and chronic diseases in rural communities have received little attention (Perri et al., 2008). As an initial step in planning future research, the authors of this report completed a systematic review of interventions 
related to dietary intake and physical activity targeting rural populations in the US. The goals were to examine the effectiveness of lifestyle interventions in rural communities and to determine salient features for replication in future studies.

\section{METHODS}

The present review is based upon bibliographic searches of PubMed and CINAHL with relevant search terms. Articles published in English through March 15, 2016, were identified using the following MeSH search terms and Boolean algebra commands: (((dietary intake) or (diet) or (nutrition) AND (physical activity) or (exercise)) AND (rural)). Although the search criteria did not specify a begin date, the earliest article that met the search criteria was published in 2004. The searches were not limited to words appearing in the titles of articles. Information obtained from bibliographic searches (title and topic of article, information in abstract, geographic locality of a study, and key words) was used to determine whether to retain each article. In addition, reports included in Cochrane reviews (http:// community.cochrane.org/cochrane-reviews) were identified. Only completed studies were included; study protocols were eliminated (Figure 2); 154 citations were found.

After screening the abstracts or full texts of these articles, 50 studies of rural populations were identified, all of which were conducted in the US. The inclusion criteria were completed studies of interventions focusing on dietary intake and/or physical activity and performed in rural areas in the US. Thirty-two reports that did not meet the inclusion criteria were not considered further. The two eligible studies identified in the CINAHL search overlapped with those identified in the PubMed search.

\section{RESULTS}

A total of 18 studies met the search criteria (Table 1). Six included a randomized controlled approach; 7 used quasi-experimental designs; 4 had a pre-/post-design; and 1 was an observational study. Eight studies were multisite or multi-county, and 3 focused on churches or other institutions within rural communities. Primary emphasis by racial/ethnic group included: African Americans (6), Whites (2), Hispanics (3), and two or more groups (7). Most studies (17) focused on adults; 1 included children. Two studies targeted families.

Befort et al. (2012) conducted a quasi-experimental study with 35 White obese breast cancer survivors aged 46-74 years from three cancer centers in rural Kansas. The 6-month, groupbased, weight control intervention incorporated self-regulation skills and social support to enhance changes in diet and physical activity. There were significant post-intervention changes for weight (>10\% loss), fruit and vegetable consumption ( $+3.7 \pm 4.3$ servings/day), and physical activity $(+1235 \pm 832 \mathrm{kcal} /$ week), and reductions in two biochemical mediators of breast cancer risk, fasting insulin $(-16.7 \%)$ and leptin $(-37.1 \%)$.

Brown et al. (2011) performed a pre-test, post-test control group study of 165 Mexican American men and women aged 35-70 living in a rural community on the Texas-Mexico border. The 6-month intervention compared culturally tailored diabetes self-management education (DSME) alone to DSME plus nurse case management (NCM). For both groups, positive changes in diet and physical activity and clinical outcomes were noted. Women had 
greater reductions in BMI relative to men. Participants with the most NCM contacts attended more DSME sessions, and higher attendance resulted in greater reductions in $\mathrm{HbA}_{1 \mathrm{c}}$ levels.

Carter et al. (2015) engaged 55 African American men and women in a year-long intervention in two rural Alabama counties (Bullock and Macon). For those in Macon County, physical activity included membership in Curves, floor exercise, or walking; those in Bullock County engaged in aerobics, dance, the gym, or walking. Individuals doing floor exercise lost the most weight ( $22.4 \mathrm{lb}$ or $11.18 \%$ change) followed by those walking ( $6.1 \mathrm{lb}$ or $3.40 \%$ change). For all physical activities, systolic and diastolic blood pressure decreased ( -8.94 to -12.66 and -5.34 to $-12.66 \mathrm{~mm} \mathrm{Hg}$, respectively).

Fahs et al. (2013) compared a stage-matched nursing and community intervention (SMN $+\mathrm{CI})$ to $\mathrm{CI}$ alone in a 14-month, multisite, randomized control trial of 117 rural White, Black, and Hispanic women aged 35-65 years in rural counties in New York and Virginia. Significant increases in fruit and vegetable consumption and reduced diastolic blood pressure were noted in the $\mathrm{SMN}+\mathrm{CI}$ cohort. The CI group had a significant reduction in total cholesterol.

In rural central Nebraska, Hageman et al. (2014) conducted a 12-month randomized controlled trial to reduce blood pressure among 289 women (primarily White), ages 40-69 with hypertension. Participants were randomized to standard advice, web-based intervention, or print intervention. For the web-based and print intervention cohorts, waist circumference, $\%$ calories from fat, saturated fat, servings of fruits and vegetables, and low fat dairy improved significantly. Improvements were observed in web-based vs. standard advice groups in systolic blood pressure $(\mathrm{p}=0.048)$ and estimated $\mathrm{VO}_{2} \max (\mathrm{p}=0.037)$.

Focusing on diabetes self-management behaviors, Hu et al. (2014) completed a quasiexperimental, family-based study of 36 Hispanics (mostly women) and 37 members of their adult families. The 8-week pilot study, conducted in rural central North Carolina, consisted of two family sessions and eight weekly group sessions. Session content included education on diabetes self-management, exercise, food, and eating healthy. Among study participants, $\mathrm{HbA}_{1 \mathrm{c}}$ dropped by a mean of $0.41 \%$ from baseline to 1-month post-intervention.

In two rural counties in southwest Georgia, Kegler et al. (2012) conducted a coach-based, quasi-experimental intervention to improve food quality and physical activity in 90 households. Participating in the 6-week study were African American and White adults ages 40-70 years and their household members 18 years of age or older. Intervention households reported increased exercise relative to comparison households.

Kim et al. (2008) conducted a study of a faith-based weight loss intervention. With an intervention group and a delayed-intervention control group, a quasi-experimental design was used. The 73 participants ( $71 \%$ female, mean age 54.1 years, 100\% African American) were from rural churches in North Carolina. Small groups led by trained community members met weekly for 8 weeks. The community members emphasized physical activity, healthy nutrition, and the connection of faith to health. The mean weight loss in the intervention group was $3.60 \mathrm{lb}$ relative to $0.59 \mathrm{lb}$ in the control group. 
Landry et al. (2015) completed a 6-month, community-based, pre-post trial of an intervention consisting of motivational enhancement, social support, pedometer diary selfmonitoring, and educational sessions. The participants were 269 adults (94\% African American, $85 \%$ female, mean age 44 years) in Hattiesburg, Mississippi. The outcome measures were steps per day, fitness, dietary intake, and psychosocial construct measures. For the physical activity and dietary outcome variables, there were temporal changes only for steps per day and sugar intake. Sugar intake decreased by about 3 teaspoons, and physical activity increased by approximately 2,010 steps per day.

In a multi-site, cardiovascular disease prevention study, Lilly et al. (2014) investigated barriers to lifestyle change among 81 white, Hispanic, and African American women in Colorado, North Carolina, and West Virginia. Most participants (72\%) reported significant post-intervention improvements in problem-solving skills $(\mathrm{p}<0.001)$, perceived stress $(\mathrm{p}<0.05)$, and maintenance of or increases in fruit and vegetable intake and physical activity.

Mayer-Davis et al. (2004) conducted a 12-month randomized clinical trial of 152 African American and White diabetic men and women in rural South Carolina. The study evaluated the effectiveness of a Diabetes Prevention Program-type intervention (intensive intervention), reimbursable-lifestyle intervention, and usual care (controls) on weight loss and $\mathrm{HbA}_{1 \mathrm{c}}$. Relative to controls, intensive-intervention participants had greater weight loss than controls $(-2.6 \mathrm{~kg}$ vs. $-0.4 \mathrm{~kg}, \mathrm{p}<0.01)$. $\mathrm{HbA}_{1 \mathrm{c}}$ was reduced among all participants $(\mathrm{p}<0.05)$ but was not different between cohorts.

In three rural counties in South Carolina, Parker et al. (2010) conducted a church-based weight loss intervention among African American women. The study was developed with community involvement. The 35 participants, between the ages of 25 and 64 years, were not pregnant or breast-feeding. Two 10-week interventions (spiritually-based and nonspiritually-based) were pilot tested using a pre-post design. Physical activity was assessed using the Yale Physical Activity Survey. Both interventions led to significant reductions in BMI, but the spiritually-based intervention $(\mathrm{z}=-1.97, \mathrm{P}<0.01)$ led to greater reductions. For the spiritually-based group, significant improvements were found for physical activity $(z=$ $-2.74, \mathrm{P}<0.01)$.

In three rural North Carolina counties, Ries et al. (2014) conducted a project with a quasiexperimental design. The participants were 485 low-income, predominately minority women (63\% African American) with a mean age of 47.5 years. The curriculum for the bi-weekly group meetings, held over a 6-month period, addressed physical activity, healthy eating, weight control, stress management, education, and job skills. For both African Americans $(\mathrm{P}<0.05)$ and whites $(\mathrm{P}<0.0001)$, intervention participants were more likely than comparison participants to move from contemplation to action/maintenance in regard to the goal of increasing physical activity. For all participants, progression in stages of change mediated the intervention effect on physical activity but not fruit and vegetable intake. Intervention group participants engaged in more minutes of physical activity per week (138 minutes) than comparison participants ( 86 minutes, $\mathrm{P} \unlhd 0.05$ ). 
Robles et al. (2014) conducted a 12-week prospective study of 33 children aged 8-11 years in Bailey County, Texas. The purpose was to assess the impact of a pharmacy-directed pilot study on dietary intake and physical activity during out-of-school time. Post-intervention changes were noted in BMI $(-0.30, \mathrm{p}<0.0001)$, waist circumference $(-0.47, \mathrm{p}<0.001)$, decreased consumption of fried/sweet foods, and increased exercise.

In Alabama's "Black Belt," Scarinci et al. (2014) conducted a community-based, clusterrandomized trial comparing two interventions: 1) promotion of physical activity and healthy eating (healthy lifestyle arm), and 2) promotion of breast and cervical cancer screening. Participants were 565 African American women of ages 45-65 years in six rural counties in Alabama. At the 12-month follow-up, participants in the healthy lifestyle arm showed significant positive changes (increased physical activity, increased fruit/vegetable intake, and decreased consumption of fried food). At 24 months, these positive changes were maintained for healthy eating behaviors but not for physical activity.

In a quasi-experimental, 6-month intervention related to diet and physical activity, TussingHumphreys et al. (2013) assigned eight churches to intervention or control. Conducted in the Lower Mississippi Delta Region, the study included 403 African American men and women with a mean age of 47 years. Adapted from the Body and Soul program (Resnicow et al., 2004), Delta Body and Soul included peer counseling, a focus on regional cuisine, a didactic physical activity session, and self-directed physical activity. In both study arms, there were significant increases for consumption of total fruits and vegetables (0.3[1.8] and 0.2[1.1]), aerobic physical activity (22\%), and strength/flexibility (24\%).

In the "Wellness for Women" clinical trial, Walker et al. (2009) randomly assigned 225 women from two similar rural areas to cohorts receiving a computer-tailored newsletter or a generic newsletter. The 12-month intervention and 12-month follow-up examined behavioral markers of activity and eating. Relative to the generic cohort, at 6 months and at 12 months, the 'tailored' group achieved greater strength $(\mathrm{p}=0.008$ and $\mathrm{p}=0.002)$ and consumed a lower percent of calories from saturated fat $(\mathrm{p}=0.028$ and $\mathrm{p}<0.001)$, respectively.

Zoellner et al. (2007) conducted a quasi-experimental study to evaluate a 6-month intervention focused on promoting physical activity and health through walking teams led by coaches, with self-monitoring and monthly 1-hour educational sessions. The participants were 83 rural residents in Hollandale, Mississippi (99\% African American, 97\% women). There were improvements in waist circumference ( -1.4 inches), systolic blood pressure $(-4.3 \mathrm{mmHg})$, and HDL-cholesterol $(+7.9 \mathrm{mg} / \mathrm{dL})(\mathrm{p}<0.001)$. Self-reported walking per day was $44.8(\mathrm{SD} \pm 52.2)$ minutes at enrollment and $65.9(\mathrm{SD} \pm 89.7)$ minutes at 6 months $(\mathrm{P}=0.154)$.

\section{DISCUSSION}

In the US, rural communities are a large, medically underserved group. Although rural populations in the US have higher rates of chronic diseases than non-rural areas (Befort et al., 2012; Patterson et al., 2004; Eberhardt et al., 2001), there are few interventions that address lifestyle risk factors among rural populations. We reviewed eighteen interventions 
targeting lifestyle that were implemented in rural areas in the US. Most of the interventions found, among study participants, significant positive changes in measurable outcomes, such as weight loss, increase in levels of physical activity, and consumption of fruits and vegetables and improvements in biochemical mediators. Only six of the studies used a randomized controlled approach, and only one, by Kegler et al. (2012), was conducted in rural Georgia.

Physical activity and a healthy diet continue to gain recognition as lifestyle interventions for use in primary and secondary prevention (Durstine et al., 2013; Warburton et al., 2006; Willett, 2002). Finding effective methods to reach and influence behavior change in residents of rural communities, who are at high risk for developing chronic diseases, is a public health challenge. In rural America, sociocultural and personal barriers, including the stress of living in poverty, low health literacy, and lack of experience and skill in accessing healthcare information services, remain as obstacles (Brown et al. 2011).

Most of the studies covered in this review employed strategies that were mindful of the socioeconomic barriers to healthcare delivery encountered by rural dwellers. The strategies included community-based participatory research (CBPR), distance-delivery methods (webbased, telephone, and mail), and case management.

CBPR, a framework through which evidence-based interventions (e.g., randomized trials) are developed and implemented in the context of community engagement, offers a partnership approach to research that equitably involves community members, organizational representatives, and researchers in all aspects of the research process (Scarinci et al., 2014). It enhances cultural appropriateness and encourages the building of trust between researchers and community members, thereby facilitating recruitment of participants. Carter et al. (2015), Kegler et al. (2012), Kim et al. (2008), Ries et al. (2014), and Scarinci et al. (2014) utilized the CBPR approach. Distance-delivery methods for implementing lifestyle modification interventions show promise for reaching rural women. The weight-loss intervention by Befort et al (2012) examined the effect of a group-based, weight control intervention delivered through conference call technology to obese breast cancer survivors living in remote rural locations. The intervention included weekly group phone sessions and a reduced-calorie diet incorporating prepackaged entrees and shakes. Physical activity gradually increased to $225 \mathrm{~min} /$ week of moderate intensity exercise. There were also significant changes for weight, diet, physical activity, serum biomarkers, and quality of life. Hageman et al. (2014) also utilized the distance-delivery method. Women in groups who had the intervention delivered by the web or print-mailed, improved more than the group receiving standard advice in regard to waist circumference, daily calories from fat, and daily servings of fruit and vegetables. Lifestyle modification interventions that incorporate web-based components offer advantages of providing tailored messages at low cost in order to reach a large audience across great distances, with convenience for the users. Case management is a strategy to coordinate healthcare services and provide more consistent levels of health care access. Brown et al. (2011) studied changes in diet and physical activity between an experimental group that was administered a diabetes self-management education (DSME) with access to a nurse case manager (NCM), and another group that had DSME only. Although there was non-significant improvement in diet and physical activity between 
the two groups, the number of NCM contacts was proportional to DSME attendance. Case managers, who help patients locate and manage resources, are advocates within the healthcare system who enhance communication among healthcare providers, patients, and their families (Brown et al. 2011).

The reviewed studies had various limitations. Most (11) had small sample sizes and uncertain generalizability; 5 lacked a control group; and 5 with control groups lacked randomization. Studies by Kegler et al. (2012), Lilly et al. (2014), and Robles et al. (2014) had short intervention periods. In some of the studies, self-reporting of dietary intake and physical activity were limitations.

For rural America and for Georgia in particular, there is paucity of evidence-based studies about lifestyle modification interventions. To achieve health equity between rural and urban communities, increased funding for research activities targeting lifestyle interventions in rural areas is needed. The promotion of more tailored interventions that increase physical activity and consumption of healthy diets among rural residents and that address the limitations of existing studies, is warranted.

\section{CONCLUSIONS}

Relative to urban residents, rural residents are disadvantaged in terms of socioeconomic determinants of health, access to and availability of healthcare resources, and facilities that reduce lifestyle risk for chronic diseases. Consequently, among rural communities, the prevalence of chronic diseases is high. Although the few studies on lifestyle interventions in rural areas have generally found favorable outcomes, studies that include rigorous designs and adequate sample sizes and produce generalizable results are needed.

\section{Acknowledgments}

The National Cancer Institute (R01CA166785) funded this work.

\section{References}

Aldana, SG. The Culprit \& The Cure: Why Lifestyle is the Culprit Behind America's Poor Health and How Transforming That Lifestyle can be the Cure. Maple Mountain Press; 2005.

American Cancer Society (ACS). Cancer Facts \& Figures 2016. Available online: http:// www.cancer.org/acs/groups/content/@ research/documents/document/acspc-047079.pdf. Accessed on March 18, 2016

Befort CA, Klemp JR, Austin HL, Perri MG, Schmitz KH, Sullivan DK, Fabian CJ. Outcomes of a weight loss intervention among rural breast cancer survivors. Breast Cancer Research and Treatment. 2012; 132(2):631-639. [PubMed: 22198470]

Befort CA, Nazir N, Perri MG. Prevalence of obesity among adults from rural and urban areas of the United States: findings from NHANES (2005 2008). The Journal of Rural Health. 2012; 28(4):392397. [PubMed: 23083085]

Bennett, KJ.; Olatosi, B.; Probst, JC. Health disparities: a rural-urban chartbook, 2008. Columbia, SC: South Carolina Rural Health Research Center; 2013.

Blackwell DL, Lucas JW, Clarke TC. Summary health statistics for US adults: national health interview survey, 2012. Vital and health statistics. 2014; (260):1-161. [PubMed: 24819891] Series 10, Data from the National Health Survey 
Brown SA, García AA, Winter M, Silva L, Brown A, Hanis CL. Integrating education, group support, and case management for diabetic Hispanics. Ethnicity \& Disease. 2011; 21(1):20-26. [PubMed: 21462725]

Carter VL, Dawkins NL, Howard B. Weight and blood pressure reduction among participants engaged in a cancer awareness and prevention program. Preventive Medicine Reports. 2015; 2:858-861. [PubMed: 26601053]

Cecchini M, Sassi F, Lauer JA, Lee YY, Guajardo-Barron V, Chisholm D. Tackling of unhealthy diets, physical inactivity, and obesity: health effects and cost-effectiveness. The Lancet. 2010; 376(9754): $1775-1784$.

Drozek D, Diehl H, Nakazawa M, Kostohryz T, Morton D, Shubrook JH. Short-Term Effectiveness of a Lifestyle Intervention Program for Reducing Selected Chronic Disease Risk Factors in Individuals Living in Rural Appalachia: A Pilot Cohort Study. Advances in Preventive Medicine. 2014; $2014: 7$.

Durstine JL, Gordon B, Wang Z, Luo X. Chronic disease and the link to physical activity. Journal of Sport and Health Science. 2013; 2(1):3-11.

Eberhardt, MS.; Ingram, DD.; Makuc, DM. Urban and rural health chartbook: Health, United States 2001. Hyattsville, MD: National Center for Health Statistics; 2001.

Fahs PS, Pribulick M, Williams IC, James GD, Rovynak V, Seibold-Simpson SM. Promoting heart health in rural women. The Journal of Rural Health. 2013; 29(3):248-257. [PubMed: 23802927]

Hageman PA, Pullen CH, Hertzog M, Boeckner LS. Effectiveness of tailored lifestyle interventions, using web-based and print-mail, for reducing blood pressure among rural women with prehypertension: main results of the Wellness for Women: DASHing towards Health clinical trial. International Journal of Behavioral Nutrition and Physical Activity. 2014; 11(1):148. [PubMed: 25480461]

Hu J, Wallace D, McCoy T, Amirehsani K. A Family-Based Diabetes Intervention for Hispanic Adults and Their Family Members. The Diabetes Educator. 2014; 40(1):48-59. [PubMed: 24248832]

Kegler MC, Alcantara I, Veluswamy J, Haardörfer R, Hotz JA, Glanz K. Results from an intervention to improve rural home food and physical activity environments. Progress in Community Health Partnerships: Research, Education, and Action. 2012; 6(3):265-277.

Kim KH, Linnan L, Campbell MK, Brooks C, Koenig HG, Wiesen C. The WORD (wholeness, oneness, righteousness, deliverance): a faith-based weight-loss program utilizing a communitybased participatory research approach. Health Education \& Behavior. 2008; 35:634-650. [PubMed: 17200103]

Landry AS, Thomson JL, Madson MB, Zoellner JM, Mohn RS, Noble J, Connell CL, Yadrick K. Peer Reviewed: Psychosocial Constructs and Postintervention Changes in Physical Activity and Dietary Outcomes in a Lifestyle Intervention, Hub City Steps, 2010. Preventing Chronic Disease. 2015; 12:140525.

Levi, J.; Segal, LM.; Rayburn, J.; Martin, A. The State of Obesity: Better Policies for a Healthier America: 2015. Trust for America's Health. 2015. Available online: ([http://stateofobesity.org/ files/stateofobesity2015.pdf][http://stateofobesity.org/states/ga/]) Accessed on March 18, 2016

Lilly CL, Bryant LL, Vu MB, Hill-Briggs F, Samuel-Hodge CD, McMilin CR, Keyserling TC. Evaluation of the Effectiveness of a Problem-Solving Intervention Addressing Barriers to Cardiovascular Disease Prevention Behaviors in 3 Underserved Populations: Colorado, North Carolina, West Virginia, 2009. Preventing Chronic Disease. 2014; 11:130249.

Mayer-Davis EJ, D'Antonio AM, Smith SM, Kirkner G, Levin Martin S, Parra-Medina D, Schultz R. Pounds off with empowerment (POWER): a clinical trial of weight management strategies for black and white adults with diabetes who live in medically underserved rural communities. American Journal of Public Health. 2004; 94(10):1736-1742. [PubMed: 15451743]

McNamara, C.; Chung, A.; Bayakly, AR. Georgia Cancer Data Report, 2014. Georgia Department of Public Health, Georgia Comprehensive Cancer Registry; Sep. 2015 Available online: https:// dph.georgia.gov/sites/dph.georgia.gov/files/Cancer_2014_Final.pdf Accessed on March 18, 2016

Parker VG, Coles C, Logan BN, Davis L. The LIFE project: a community-based weight loss intervention program for rural African American women. Family \& Community Health. 2010; 33(2):133-143. [PubMed: 20216356] 
Patterson PD, Moore CG, Probst JC, Shinogle JA. Obesity and physical inactivity in rural America. The Journal of Rural Health. 2004; 20(2):151-159. [PubMed: 15085629]

Perri MG, Limacher MC, Durning PE, Janicke DM, Lutes LD, Bobroff LB, Dale MS, Daniels MJ, Radcliff TA, Martin AD. Extended-care programs for weight management in rural communities: the treatment of obesity in underserved rural settings (TOURS) randomized trial. Archives of Internal Medicine. 2008; 168(21):2347-2354. [PubMed: 19029500]

Resnicow K, Campbell MK, Carr C, McCarty F, Wang T, Periasamy S, Rahotep S, Doyle C, Williams A, Stables G. Body and soul: a dietary intervention conducted through African-American churches. American Journal of Preventive Medicine. 2004; 27(2):97-105. [PubMed: 15261895]

Ricanati EH, Golubić M, Yang D, Saager L, Mascha EJ, Roizen MF. Mitigating preventable chronic disease: Progress report of the Cleveland Clinic's Lifestyle 180 program. Nutrition \& Metabolism. 2011; 8(1):1. [PubMed: 21241467]

Ries AV, Blackman LT, Page RA, Gizlice Z, Benedict S, Barnes K, Kelsey K, Carter-Edwards L. Goal setting for health behavior change: evidence from an obesity intervention for low-income women. Rural Remote Health. 2014; 14:1-14.

Robles J, Gutierrez A, Seifert CF. Impact of a pilot pharmacy health-care professional out-of-school time physical activity and nutrition education program with exercise on fourth and fifth graders in a rural Texas community. SAGE Open Medicine. 2014; 2205031211454795.

Scarinci IC, Moore A, Wynn-Wallace T, Cherrington A, Fouad M, Li Y. A community-based, culturally relevant intervention to promote healthy eating and physical activity among middle-aged African American women in rural Alabama: Findings from a group randomized controlled trial. Preventive Medicine. 2014; 69:13-20. [PubMed: 25152504]

Tussing-Humphreys L, Thomson JL, Mayo T, Edmond E. A Church-Based Diet and Physical Activity Intervention for Rural, Lower Mississippi Delta African American Adults: Delta Body and Soul Effectiveness Study, 2010-2011. Preventing Chronic Disease. 2013; 10:120286.

United States Department of Agriculture (USDA). Economic Research Service (ERS). State Fact Sheets: Georgia. 2016. Available online: http://www.ers.usda.gov/data-products/state-fact-sheets/ state-ata.aspx StateFIPS =13\&StateName=Georgia Accessed March 30, 2016

Walker SN, Pullen CH, Boeckner L, Hageman PA, Hertzog M, Oberdorfer MK, Rutledge MJ. Clinical trial of tailored activity and eating newsletters with older rural women. Nursing Research. 2009; 58(2):74-85. [PubMed: 19289928]

Warburton DE, Nicol CW, Bredin SS. Health benefits of physical activity: the evidence. Canadian Medical Association Journal. 2006; 174(6):801-809. [PubMed: 16534088]

Ward BW, Schiller JS, Goodman RA. Multiple Chronic Conditions Among US Adults: A 2012 Update. Preventing Chronic Disease. 2014; 11:130389.

Willett WC. Balancing life-style and genomics research for disease prevention. Science. 2002; 296(5568):695-698. [PubMed: 11976443]

Willett, WC.; Koplan, JP.; Nugent, R.; Dusenbury, C.; Puska, P.; Gaziano, TA. Prevention of chronic disease by means of diet and lifestyle changes. In: Jamison, DT.; Breman, JG.; Measham, AR., et al., editors. Disease control priorities in developing countries. World Bank Publications; 2006.

Zoellner J, Hill JL, Grier K, et al. Randomized controlled trial targeting obesity-related behaviors: Better Together Healthy Caswell County. Preventing Chronic Disease. 2013; 10:E96. [PubMed: 23764345] 

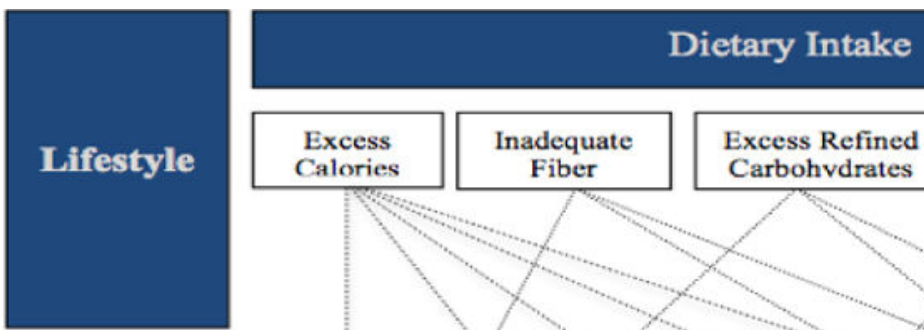

Physical Activity
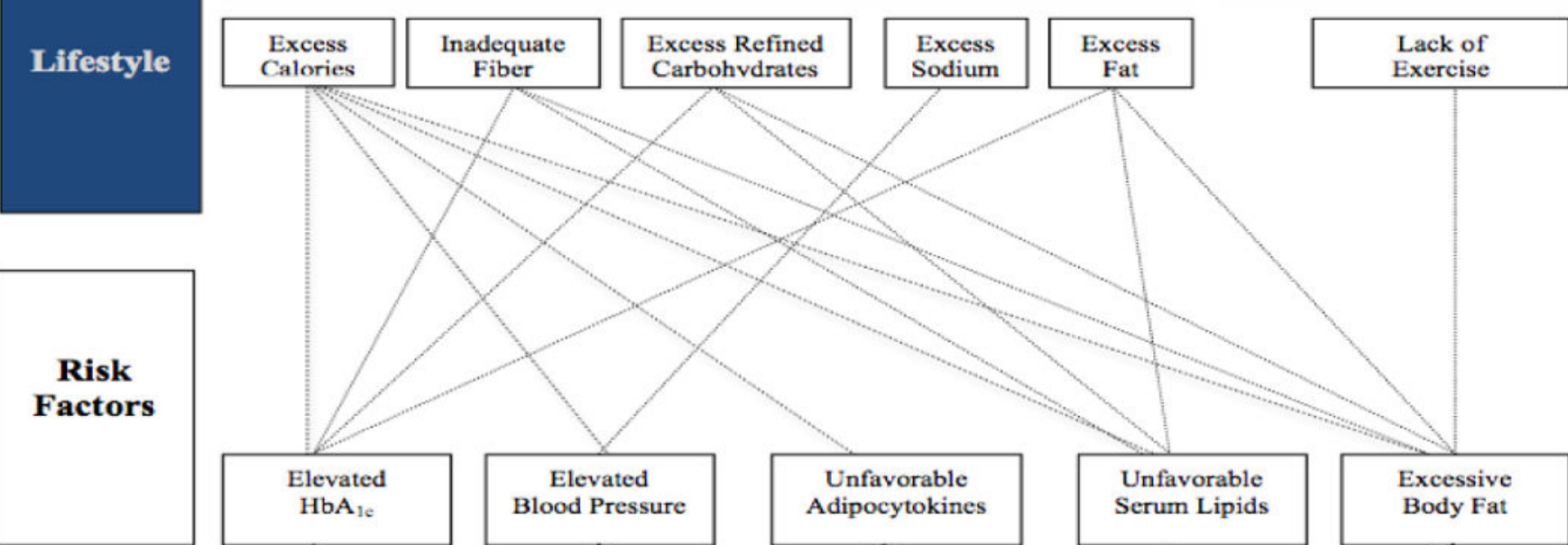
Fiber Carbohvdrates

Fat Exercise
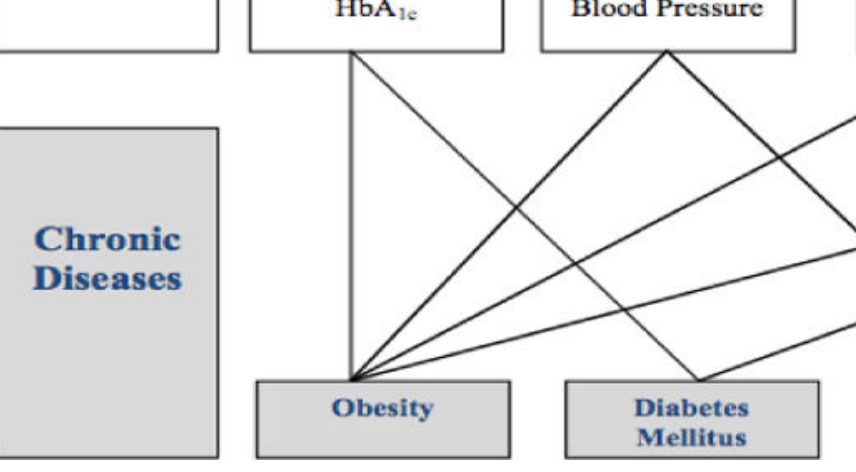

Figure 1.

Lifestyle, risk factors, and chronic diseases 


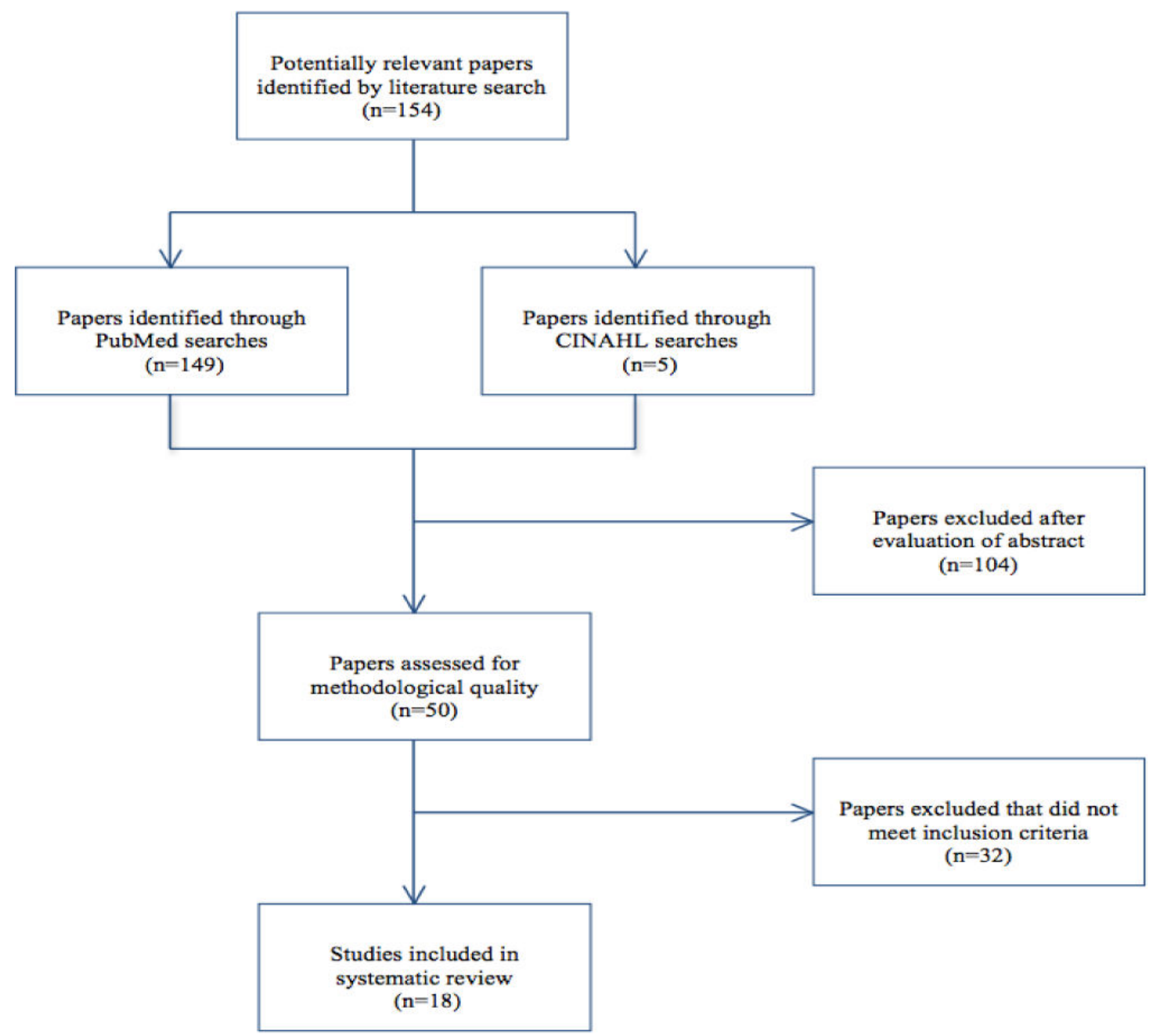

Figure 2.

Flowchart of intervention selection process 
Table 1

Dietary intake and physical activity interventions in rural populations

\begin{tabular}{|c|c|c|c|c|}
\hline Study & Design & Sample & Results & Limitatios \\
\hline $\begin{array}{l}\text { Befort et al. } \\
\quad(2012)\end{array}$ & $\begin{array}{l}\text { Quasi-experimental } \\
\text { one-arm (6-month) } \\
\text { group phone-based } \\
\text { weight control } \\
\text { intervention addressing } \\
\text { lifestyle modification } \\
\text { and breast cancer risk }\end{array}$ & $\begin{array}{l}34 \text { White women ages } \\
46-74 \text { years from three } \\
\text { rural cancer centers in } \\
\text { Kansas }\end{array}$ & $\begin{array}{l}\text { Significant changes for weight } \\
(-12.5 \pm 5.8 \mathrm{~kg}) \text {; waist } \\
\text { circumference }(-9.4 \pm 6.3 \mathrm{~cm}) \text {; daily } \\
\text { energy intake }(-349 \pm 550 \mathrm{kcal} / \text { day }) \text {; } \\
\text { fruits and vegetables }(3.7 \pm 4.3 \\
\text { servings } / \text { day }) ; \text { percent kcal from fat } \\
(-12.6 \pm 8.6 \%) \text {; and physical } \\
\text { activity }(1235 \pm 832 \mathrm{kcal} / \text { week } \\
(p<0.001) \text { were observed. }\end{array}$ & $\begin{array}{l}\text { Small sample size; lack of a } \\
\text { control group; uncertain } \\
\text { generalizability }\end{array}$ \\
\hline $\begin{array}{l}\text { Brown et al. } \\
\quad(2011)\end{array}$ & $\begin{array}{l}\text { Pre-test, post-test } \\
\text { control group design } \\
\text { with two groups: } \\
\text { experimental (diabetes } \\
\text { self-management } \\
\text { education or DSME } \\
\text { with access to a nurse } \\
\text { case manager or NCM } \\
\text { vs. DSME only) }\end{array}$ & $\begin{array}{l}165 \text { Mexican American } \\
\text { men and women ages } \\
35-70 \text { years in Starr } \\
\text { County, Texas }\end{array}$ & $\begin{array}{l}\text { There were non-significant } \\
\text { improvements in diet and physical } \\
\text { activity among experimental and } \\
\text { comparison cohorts. Regardless of } \\
\text { study arm, compared to men, women } \\
\text { had significant reductions in body } \\
\text { mass index (BMI). The number of } \\
\text { NCM contacts was proportional to } \\
\text { DSME attendance. }\end{array}$ & $\begin{array}{l}\text { Small sample size; uncertain } \\
\text { generalizability }\end{array}$ \\
\hline $\begin{array}{l}\text { Carter et al. } \\
\quad(2015)\end{array}$ & $\begin{array}{l}\text { Observational study } \\
\text { (12-week) dietary } \\
\text { intake, physical } \\
\text { intervention, and } \\
\text { hypertension }\end{array}$ & $\begin{array}{l}55 \text { ( } 39 \text { female, } 16 \text { male }) \\
\text { African Americans ages } \\
35-75 \text { years in Bullock } \\
\text { County and Macon } \\
\text { County, Alabama }\end{array}$ & $\begin{array}{l}\text { Among Bullock county participants, } \\
\text { body weight decreases ranged from } \\
0.69 \text { to } 3.40 \% \text {, with the exception of } \\
\text { a dance group. In Macon County } \\
\text { participants lost weight irrespective } \\
\text { of the exercise regimen, with those } \\
\text { involved in floor exercise losing the } \\
\text { most weight }(11.18 \%) \text {. }\end{array}$ & $\begin{array}{l}\text { Small sample size, lack of a } \\
\text { control group; uncertain } \\
\text { generalizability }\end{array}$ \\
\hline $\begin{array}{l}\text { Fahs et al. } \\
\quad(2013)\end{array}$ & $\begin{array}{l}\text { Multi-site randomized } \\
\text { control trial (14 } \\
\text { months) comparing } 2 \\
\text { strategies (stage- } \\
\text { matched nursing } \\
\text { (SMN) and community } \\
\text { intervention (CI) vs. CI } \\
\text { alone) in changing } \\
\text { CVD risk factors (diet, } \\
\text { physical activity, } \\
\text { and/or smoking) }\end{array}$ & $\begin{array}{l}117 \text { non-Hispanic } \\
\text { White }(87.2 \%) \text { Black } \\
(8.5 \%) \text { and Hispanic } \\
(1.7 \%) \text { women with a } \\
\text { mean age of } 50 \text { years } \\
\text { from } 1 \text { rural county in } \\
\text { New York and } 2 \text { rural } \\
\text { counties in Virginia }\end{array}$ & $\begin{array}{l}\text { The SMN + CI cohort had } \\
\text { significant increases in fruits and } \\
\text { vegetables and reduced diastolic } \\
\text { blood pressure; CI participants had } \\
\text { significant reductions in cholesterol. } \\
\text { For both groups, Framingham risk } \\
\text { scores were reduced significantly } \\
\text { post-intervention. }\end{array}$ & $\begin{array}{l}\text { Small sample size, high } \\
\text { attrition rate, uncertain } \\
\text { generalizability; possible } \\
\text { contamination across cohorts }\end{array}$ \\
\hline $\begin{array}{l}\text { Hageman et } \\
\text { al. (2014) }\end{array}$ & $\begin{array}{l}\text { Three-arm community- } \\
\text { based clinical trial (12- } \\
\text { month intervention } \\
\text { with } 12 \text {-month follow- } \\
\text { up) comparing standard } \\
\text { advice, intervention } \\
\text { Internet or intervention } \\
\text { print related to } \\
\text { hypertension }\end{array}$ & $\begin{array}{l}289 \text { women ages } 40-49 \\
\text { years (mean age } 56.4 \\
\text { years) primarily white } \\
(98 \%) \text { from central } \\
\text { Nebraska }\end{array}$ & $\begin{array}{l}\text { Web-based and print-mailed groups } \\
\text { improved more than standard advice } \\
\text { group for waist circumference }(\mathrm{p}= \\
0.017 \text { and } \mathrm{p}=0.016 \text {, respectively); } \\
\% \text { daily calories from fat }(\mathrm{p}=0.018 \\
\text { and } \mathrm{p}=0.030) \text { and saturated fat }(\mathrm{p}= \\
0.049 \text { and } \mathrm{p}=0.013) \text {; daily servings } \\
\text { of fruit and vegetables }(\mathrm{p}=0.008 \\
\text { and } \mathrm{p}<0.005) \text {; and low fat dairy ( } \mathrm{p} \\
<0.001 \text { and } \mathrm{p}=0.002)\end{array}$ & $\begin{array}{l}\text { Self-reported physical activity } \\
\text { outcomes; possible } \\
\text { contamination across cohorts }\end{array}$ \\
\hline $\begin{array}{l}\text { Hu et al. } \\
(2014)\end{array}$ & $\begin{array}{l}\text { Quasi-experimental } \\
\text { family-based } \\
\text { intervention (8-weeks) } \\
\text { pilot study of diabetes } \\
\text { self-management } \\
\text { behaviors }\end{array}$ & $\begin{array}{l}26 \text { Hispanic men }(25 \%) \\
\text { and women }(75 \%) \\
\text { average age } 50 \text { years } \\
\text { and } 37 \text { family members, } \\
\text { men }(30 \%) \text { and women } \\
(70 \%) \text { average age } 40.6 \\
\text { years in rural central } \\
\text { North Carolina }\end{array}$ & $\begin{array}{l}\text { Participants had higher levels of } \\
\text { intake of healthy foods post- } \\
\text { intervention. No significant changes } \\
\text { in levels of physical activity were } \\
\text { found among patients with diabetes } \\
\text { or family members. }\end{array}$ & $\begin{array}{l}\text { Small sample size, no control } \\
\text { group; lack of randomization, } \\
\text { uncertain generalizability }\end{array}$ \\
\hline $\begin{array}{l}\text { Kegler et al. } \\
\quad(2012)\end{array}$ & $\begin{array}{l}\text { Quasi-experimental } \\
\text { design coach-based (6- } \\
\text { week) intervention } \\
\text { (family goal setting } \\
\text { and behavioral } \\
\text { contracting to make } \\
\text { home environments } \\
\text { more supportive of }\end{array}$ & $\begin{array}{l}90 \text { households with } \\
\text { African American and } \\
\text { White men and women } \\
40-70 \text { years and } 18 \\
\text { years in Cook County } \\
\text { and Randolph County, } \\
\text { Georgia }\end{array}$ & $\begin{array}{l}\text { Intervention households reported } \\
\text { significant improvements in food } \\
\text { inventories, purchasing of fruit and } \\
\text { vegetables, healthier meal } \\
\text { preparation, meals with the TV off, } \\
\text { family support for healthy eating, } \\
\text { increased exercise equipment, and } \\
\text { family support for physical activity }\end{array}$ & $\begin{array}{l}\text { Small sample size, lack of } \\
\text { randomization, insufficient } \\
\text { intervention period, less } \\
\text { intensive intervention }\end{array}$ \\
\hline
\end{tabular}




\begin{tabular}{|c|c|c|c|c|}
\hline Study & Design & Sample & Results & Limitatios \\
\hline & $\begin{array}{l}\text { healthy eating and } \\
\text { physical activity) } \\
\text { related to obesity }\end{array}$ & & $\begin{array}{l}\text { relative to comparison households. } \\
\text { Intervention households also } \\
\text { reported that the percent of fat intake } \\
\text { decreased significantly, but there } \\
\text { were no changes for fruit and } \\
\text { vegetable intake, physical activity, or } \\
\text { weight among intervention relative } \\
\text { to comparison households. }\end{array}$ & \\
\hline $\begin{array}{l}\text { Kim et al. } \\
\text { (2008) }\end{array}$ & $\begin{array}{l}\text { Quasi-experimental } \\
\text { design with an } \\
\text { intervention group and } \\
\text { a delayed intervention } \\
\text { control group }\end{array}$ & $\begin{array}{l}73 \text { African Americans } \\
\text { ( } 71 \% \text { female) mean age } \\
54.1 \text { years in rural } \\
\text { North Carolina }\end{array}$ & $\begin{array}{l}\text { Small groups led by trained } \\
\text { community members met weekly for } \\
8 \text { weeks and emphasized healthy } \\
\text { nutrition, physical activity, and } \\
\text { faith's connection to health. The } \\
\text { mean weight loss in the intervention } \\
\text { group was } 3.60 \mathrm{lb} \text {, compared to } 0.59 \\
\text { lb in the control group (P<0.001). } \\
\text { The intervention was also associated } \\
\text { with an increase in recreational } \\
\text { physical activity (P<0.01). There } \\
\text { was no significant difference in fruit } \\
\text { and vegetable consumption. }\end{array}$ & $\begin{array}{l}\text { Non-randomized design, } \\
\text { small sample size, use of self- } \\
\text { reported information, } \\
\text { uncertain generalizability }\end{array}$ \\
\hline $\begin{array}{l}\text { Landry et al. } \\
\quad(2015)\end{array}$ & $\begin{array}{l}\text { 6-month, community- } \\
\text { based, pre-post trial of } \\
\text { an intervention } \\
\text { consisting of } \\
\text { motivational } \\
\text { enhancement, social } \\
\text { support, pedometer } \\
\text { diary self-monitoring, } \\
\text { and educational } \\
\text { sessions }\end{array}$ & $\begin{array}{l}269 \text { adults (94\% } \\
\text { African American, } 85 \% \\
\text { female, mean age } 44 \\
\text { yrs) in Hattiesburg, } \\
\text { Mississippi }\end{array}$ & $\begin{array}{l}\text { For the dietary and physical activity } \\
\text { outcome variables, temporal changes } \\
\text { were observed only for sugar intake } \\
\text { and steps per day. Sugar intake } \\
\text { decreased by about } 3 \text { teaspoons and } \\
\text { physical activity increased by about } \\
2,010 \text { steps per day. }\end{array}$ & $\begin{array}{l}\text { Lack of a randomized } \\
\text { controlled design, uncertain } \\
\text { generalizability, use of self- } \\
\text { reported measures }\end{array}$ \\
\hline $\begin{array}{l}\text { Lilly et al. } \\
\text { (2014) }\end{array}$ & $\begin{array}{l}\text { Multi-site } \\
\text { observational problem } \\
\text { solving intervention to } \\
\text { address barriers to } \\
\text { lifestyle change }\end{array}$ & $\begin{array}{l}81 \text { participants average } \\
\text { age } 52.8 \text { years from } 3 \\
\text { underserved } \\
\text { populations: } 28 \\
\text { Hispanic or non- } \\
\text { Hispanic women in } \\
\text { North Carolina, } 31 \\
\text { African American } \\
\text { women in West } \\
\text { Virginia, and } 22 \text { adults } \\
\text { in Appalachia }\end{array}$ & $\begin{array}{l}\text { The intervention resulted in } \\
\text { significant improvement in problem- } \\
\text { solving skills }(\mathrm{P}<0.001) \text { and } \\
\text { perceived stress }(\mathrm{P}<0.05) \text {. Diet, } \\
\text { physical activity, and weight } \\
\text { remained stable, although } 72 \% \text { of } \\
\text { individuals reported maintenance or } \\
\text { increase in daily fruit and vegetable } \\
\text { intake, and } 67 \% \text { reported } \\
\text { maintenance or increase in daily } \\
\text { physical activity. }\end{array}$ & $\begin{array}{l}\text { Small sample size, no control } \\
\text { group, insufficient } \\
\text { intervention period, uncertain } \\
\text { generalizability }\end{array}$ \\
\hline $\begin{array}{l}\text { Mayer-Davis } \\
\text { et al. (2004) }\end{array}$ & $\begin{array}{l}\text { Randomized-controlled } \\
\text { clinical trail (12 } \\
\text { months) with } 3 \text { arms: } \\
\text { intensive intervention } \\
\text { focused on Diabetes } \\
\text { Prevention Program } \\
\text { goals; reimbursable } \\
\text { intervention and usual } \\
\text { care controls }\end{array}$ & $\begin{array}{l}152 \text { African American } \\
\text { and non-Hispanic White } \\
\text { men and women mean } \\
\text { age } 60 \text { years in two } \\
\text { rural counties in South } \\
\text { Carolina }\end{array}$ & $\begin{array}{l}\text { Participants in the intensive } \\
\text { intervention lost more weight than } \\
\text { those in the usual care cohort }(2.6 \mathrm{~kg} \\
\text { vs. } 0.4 \mathrm{~kg}, \mathrm{p}<0.01) ; 12 \% \text { of the } \\
\text { intensive lifestyle participants gained } \\
\text { at least } 2 \mathrm{~kg} \text { compared with } 27 \% \text { of } \\
\text { the usual-care participants (from } \chi 2 \\
\text { statistic, } \mathrm{P}<0.05 \text { ). There were no } \\
\text { weight changes between the } \\
\text { reimbursable and usual care } \\
\text { participants. }\end{array}$ & $\begin{array}{l}\text { Small sample size, uncertain } \\
\text { generalizability }\end{array}$ \\
\hline $\begin{array}{l}\text { Parker et al. } \\
\quad(2010)\end{array}$ & $\begin{array}{l}\text { Quasi-experimental } \\
\text { (pre-post-test) } 10 \text {-week } \\
\text { intervention (spiritually } \\
\text { based vs. non- } \\
\text { spiritually based) }\end{array}$ & $\begin{array}{l}35 \text { African American } \\
\text { women (ages } 25-64 \\
\text { years) in } 3 \text { rural South } \\
\text { Carolina counties }\end{array}$ & $\begin{array}{l}\text { Both interventions led to significant } \\
\text { reductions in BMI but the spiritually } \\
\text { based intervention }(\mathrm{z}=-1.97, \\
\mathrm{P}<0.01) \text { led to greater reductions in } \\
\text { BMI. For the spiritual group, } \\
\text { statistically significant } \\
\text { improvements were found in } \\
\text { physical activity }(z=-2.74, \mathrm{P}<0.01)\end{array}$ & $\begin{array}{l}\text { Non-randomized design, } \\
\text { small sample size; uncertain } \\
\text { generalizability }\end{array}$ \\
\hline $\begin{array}{l}\text { Ries et al. } \\
\text { (2014) }\end{array}$ & $\begin{array}{l}\text { Quasi-experimental } \\
\text { two-arm community- } \\
\text { based intervention (6- } \\
\text { months) focused on } \\
\text { health information and } \\
\text { goal setting support } \\
\text { through group }\end{array}$ & $\begin{array}{l}485 \text { ( } 208 \text { intervention, } \\
277 \text { comparison) } \\
\text { women ( } 20 \% \text { White, } \\
63 \% \text { Black, and } 10 \% \\
\text { others) mean age } 47.5 \\
\text { years in rural North } \\
\text { Carolina }\end{array}$ & $\begin{array}{l}\text { Intervention compared to } \\
\text { comparison participants were more } \\
\text { likely to move from contemplation } \\
\text { to action/maintenance for the goals } \\
\text { of improving diet ( } 58 \% \text { intervention, } \\
44 \% \text { comparison, } p=0.04 \text { ) and } \\
\text { physical activity }(56 \% \text { intervention, } \\
31 \% \text { comparison, } \mathrm{p} ₫ .0001 \text { ). }\end{array}$ & Use of self-reported data \\
\hline
\end{tabular}




\begin{tabular}{|c|c|c|c|c|}
\hline Study & Design & Sample & Results & Limitatios \\
\hline & $\begin{array}{l}\text { meetings and tailored } \\
\text { newsletters }\end{array}$ & & & \\
\hline $\begin{array}{l}\text { Robles et al. } \\
\text { (2014) }\end{array}$ & $\begin{array}{l}\text { Prospective cohort } \\
\text { pilot (12-week) } \\
\text { vigorous physical } \\
\text { activity and nutrition } \\
\text { education study }\end{array}$ & $\begin{array}{l}33 \text { predominantly } \\
\text { Hispanic }(90 \%) \\
\text { overweight or obese } \\
\text { girls }(74 \%) \text { and boys } \\
\text { ages } 8-11 \text { years (mean } \\
\text { age } 9.6 \text { years) in Bailey } \\
\text { County, Texas }\end{array}$ & $\begin{array}{l}\text { Positive survey results at } 3 \text { months } \\
\text { indicated a decrease in fried/sweet } \\
\text { foods; increase in exercise; } \\
\text { decreases in video games and } \\
\text { computer use; and a change in } \\
\text { knowledge regarding the selection of } \\
\text { the most healthy food group servings } \\
\text { per day. }\end{array}$ & $\begin{array}{l}\text { Small sample size, lack of a } \\
\text { control group, short } \\
\text { intervention duration }\end{array}$ \\
\hline $\begin{array}{l}\text { Scarinci et } \\
\text { al. (2014) }\end{array}$ & $\begin{array}{l}\text { Cluster randomized } \\
\text { control trial (5-weeks) } \\
\text { randomized to either } \\
\text { healthy eating and } \\
\text { physical activity or } \\
\text { breast and cervical } \\
\text { screening with } 12 \text { and } \\
\text { 24-month follow-up }\end{array}$ & $\begin{array}{l}565 \text { African American } \\
\text { women, ages } 45-65 \\
\text { years (mean age } 53.9 \\
\text { years) randomized by } \\
\text { counties in Alabama's } \\
\text { Black Belt (Dallas, } \\
\text { Marengo, Sumter, } \\
\text { Lowndes, Green, and } \\
\text { Choctaw) }\end{array}$ & $\begin{array}{l}\text { Participants in the healthy lifestyle } \\
\text { arm ( } \mathrm{n}=188) \text { showed significant } \\
\text { positive changes compared to the } \\
\text { screening arm ( } \mathrm{n}=121) \text { at } 12 \text {-month } \\
\text { follow-up with regard to decrease in } \\
\text { fried food consumption and an } \\
\text { increase in fruit/vegetable intake } \\
(69 \%) \text { and physical activity. At } 24- \\
\text { month follow-up, these positive } \\
\text { changes were maintained with } \\
\text { healthy eating behaviors, but not } \\
\text { engagement in physical activity. }\end{array}$ & $\begin{array}{l}\text { Large detention differences } \\
\text { across intervention arms; use } \\
\text { of self-reported outcome } \\
\text { measures }\end{array}$ \\
\hline $\begin{array}{l}\text { Tussing- } \\
\text { Humphreys } \\
\text { et al. (2013) }\end{array}$ & $\begin{array}{l}\text { Quasi-experimental (6- } \\
\text { month) for improving } \\
\text { diet quality and } \\
\text { increasing physical } \\
\text { activity }\end{array}$ & $\begin{array}{l}403 \text { African American } \\
\text { men and women mean } \\
\text { age } 47 \text { assigned to } \\
\text { control }(n=208) \text { or } \\
\text { intervention }(n=195) \text { in } \\
\text { the Lower Mississippi } \\
\text { Delta region }\end{array}$ & $\begin{array}{l}\text { Diet quality components, including } \\
\text { total fruit, total vegetables, and total } \\
\text { quality improved significantly in } \\
\text { both control (mean [standard } \\
\text { deviation], } 0.3[1.8], 0.2 \text { [1.1], and } \\
3.4 \text { [9.6], respectively) and } \\
\text { intervention (0.6 [1.7], } 0.3 \text { [1.2], and } \\
3.2 \text { [9.7], respectively) groups, while } \\
\text { significant increases in aerobic } \\
(22 \%) \text { and strength/flexibility }(24 \%) \\
\text { physical activity indicators were } \\
\text { apparent only in the intervention } \\
\text { group. }\end{array}$ & $\begin{array}{l}\text { Self-reported diet and } \\
\text { physical activity, lack of } \\
\text { objective measure of physical } \\
\text { activity, uncertain } \\
\text { generalizability }\end{array}$ \\
\hline $\begin{array}{l}\text { Walker et al. } \\
\text { (2009) }\end{array}$ & $\begin{array}{l}\text { Randomized-controlled } \\
\text { community-based } \\
\text { clinical trial (12-month } \\
\text { intervention period } \\
\text { with } 12 \text { month follow- } \\
\text { up) of computer- } \\
\text { tailored newsletters } \\
\text { (intervention) vs. } \\
\text { generic newsletters } \\
\text { (control) }\end{array}$ & $\begin{array}{l}225 \text { non-Hispanic } \\
\text { White and Hispanic } \\
\text { women ages 50-69 } \\
\text { years in two similar } \\
\text { rural areas }\end{array}$ & $\begin{array}{l}\text { From baseline to } 6 \text { months, there } \\
\text { were significant increases in } \\
\text { stretching and strengthening } \\
\text { exercises, fruit and vegetable } \\
\text { servings, and decreases in \% calories } \\
\text { from fat among intervention and } \\
\text { control groups. From baseline to } 12 \\
\text { months, intervention participants had } \\
\text { greater increases in moderate } \\
\text { activity, fruit and vegetable servings, } \\
\text { and a reduction in \% fat calories. }\end{array}$ & $\begin{array}{l}\text { Self-reported measurement of } \\
\text { dietary intake and physical } \\
\text { activity; uncertain } \\
\text { generalizability }\end{array}$ \\
\hline $\begin{array}{l}\text { Zoellner et } \\
\text { al. (2013) }\end{array}$ & $\begin{array}{l}\text { Randomized control } \\
\text { pilot study (15-weeks) } \\
\text { guided by CBPR } \\
\text { principles, that } \\
\text { provided 2/weekly } \\
\text { access to group fitness } \\
\text { classes with (Group 1) } \\
\text { and without (Group 2) } \\
\text { weekly nutrition and } \\
\text { physical activity } \\
\text { education }\end{array}$ & $\begin{array}{l}91 \text { African American } \\
(62 \%) \text { and White } \\
\text { mostly female }(91 \%) \\
\text { ages } 18 \text { years of age or } \\
\text { older in the Dan River } \\
\text { Region in south-central } \\
\text { Virginia and north- } \\
\text { central North Carolina }\end{array}$ & $\begin{array}{l}\text { There were significant } \\
\text { improvements in waist } \\
\text { circumference }(-1.4 \text { inches }) \text {, systolic } \\
\text { blood pressure }(-4.3 \mathrm{mmHg}) \text {, and } \\
\text { HDL-cholesterol }(+7.9 \mathrm{mg} / \mathrm{dL}) \\
(\mathrm{p}<0.001) \text {. Self-reported walking per } \\
\text { day was } 44.8 \text { (SD } \pm 52.2) \text { minutes at } \\
\text { enrollment and } 65.9(\mathrm{SD} \pm 89.7) \\
\text { minutes at } 6 \text { months }(\mathrm{P}=0.154) \text {. }\end{array}$ & Uncertain generalizability \\
\hline
\end{tabular}

